\title{
CS Research Square \\ Unidentified Persons With Disabilities in India- A Study Based on 76th Round of NSS (2018-19) Data
}

Radhe Shyam Mishra ( $\sim$ radheshyammishra111@gmail.com )

International Institute for Population Sciences https://orcid.org/0000-0002-7452-8057

Sanjay K Mohanty

International Institute for Population Sciences

Srei Chanda

International Institute for Population Sciences

\section{Research}

Keywords: Disability certificate, Unidentified disabled, and type of disability

Posted Date: August 2nd, 2021

DOl: https://doi.org/10.21203/rs.3.rs-742723/v1

License: (9) (1) This work is licensed under a Creative Commons Attribution 4.0 International License. Read Full License 


\section{Abstract}

Background: Identification of the disabled and providing them a disability certificate is the first step for provisioning educational, employment, and other social benefits in a welfare state. Deprivation from disability certificate deprives persons with disability (PwDs) from government policy and programme. Though studies examined the extent, variation, and pattern of disability, no attempt has been made in understanding the extent and variation of unidentified PwDs in India. The study aims to examine the variation in unidentified PwDs by type of disability, state and socio-economic correlates.

Data and methods: The unit data from the 76th round (schedule 26) of Nation Sample Survey, 2018 is used in analyses. A total of 1,06,894 disabled across seven types of disabilities; any disability, locomotor, visual, hearing, speech, mental retardation, mental illness, and other disability have been analysed. Descriptive statistics and logistic regression analyses are used.

Results: 7 in 10 disabled person in India don't have a disability certificate. The percentage share of PwDs with a disability certificate varies $12 \%$ among those with hearing disability to $47 \%$ with mental retardation. Unadjusted odds ratio shows that person with hearing disability $(\mathrm{OR}=0.30 \mathrm{Cl} 0.303-0.304)$ are less likely to hold a disability certificate compare to locomotor disability followed by mental illness (OR=0.52 $\mathrm{Cl} 0.519$ 0520), and visual disability $(\mathrm{OR}=0.74 \mathrm{Cl} 0.7360 .738)$. Person with mental retardation are two times more likely to hold the disability certificate $(\mathrm{OR} 2.05 \mathrm{Cl} 2.0462 .047)$ than the visual disabled. States variation in percent share of disability certificate is found to be large. The result depicts that there remains a high variation in the access of disability certificates across states in India.

Conclusion: A nationwide drive to include the unidentified disabled is recommended with documentation and inclusion in the administrative processes.

\section{Introduction}

Identification of persons with disability (PwDs) has always been a challenge to the policy makers mainly due to definitional dissimilarities and lack of awareness at public and policy level ${ }^{1,2}$. In India, 26.8 million population are found to be disabled, which is $2.2 \%$ of the total population registered by Census of India (2011). This is measured by following the medical model through self-reported symptom-based questions. While, recently conducted survey on disability by National Sample Survey (76.25th round) also find similar prevalence for prevalence in 2018-19, though it follows new definition and categorization for disability. In the census or surveys, PwDs have been identified using several tools and classifications, despite differential measurement procedure aimed to frame an inclusive development processes in India ${ }^{3}$. Contrast in definitions are imperative to conclude the exact estimation of PwDs in India ${ }^{4,5}$. The extent of disability is very difficult to measure if not evaluated correctly. Census of India measures disability on medical model. While, the self-reporting on the functional restrictions measured in the surveys limits to justify about the intensity of disability. As there is no established study that determines the threshold for medically approved disability scores in accordance with scores of functional restrictions measured with activities of daily living. Disability certificate is a registration which identifies potential forms of disability with their level of restriction through predefined percentage share. 
Estimation of disability through an universal and appropriate definition has remained to be a question in the low and middle income countries ${ }^{6,7}$.

Until now, the major focus of the research and development pertains to infectious diseases, nutritional disparity, and other maternal and child health issues, probably due to persisting burden on the population. With the demographic and epidemiological shifts, a growing interest on ageing and incidence of chronic morbid conditions among demographers, public health researchers or policy analysists led to identify the persons with disabilities. There has been differential in the definition and conceptual measurement of disability at the global and local level ${ }^{8}$. Poor identification of disability would not only give a perspective of poor awareness among individual but also it is a failure to the whole healthcare system. Ultimately, such insufficiency would result into lower likelihood of not getting basic services provided by the state or claiming the basic rights and entitlements of the PwDs ${ }^{9}$. PwDs are prone to suffer from morbidity and functional limitations, thus, lack of access to services due to basic identification tools like disability certificate would enhance the deprivation among them 10 .

The programmes and policies delivered through the disability schemes and benefits are imperative to target the potential population at first, but seeking or registering to those services requires a government recognized disability certificate. The disability certificate is supposed to be issued by a certified medical practitioner, which is likely to be accessed in a notified hospital. Besides, Districts Disability Rehabilitation Centres (DDRCs) and PHCs have been assigned to identify the PwDs in the community. To reduce the disability burden the government has elucidated a decentralized plan that directs every primary health center for early identification and screening of the PwDs in India. The inactivity and inefficiency of the PHCs can be highlighted here that reflects under-identification of disability due to administrative failure to include the targeted population. The failure in the physical infrastructure is also complemented by the lack of knowledge, access, awareness, predefined deprivation among the demographic and socio-economic groups. A sharp difference in the prevalence of disability has been observed across regions of India7 ${ }^{7}$, as states are also going through different stages of demographic and epidemiological transitions. Hence, the policy designs and budget allocations for the health system differs depending upon the specific need of that state. It is also suggested that priorities given to the PwDs in the policy documents can find different outcomes for the identification of the PwDs. Though, centrally sponsored schemes are highlighting on the mitigation of the disability, disbursing social pensions for the PwDs, identification of the funds and other inclusive agendas; however, states plays a crucial role in identification and implementation of those benefits. The Government of Kerala has conducted an exclusive and first ever Census on disability in India, which highlights sensitivity and priority given by the state towards PwDs ${ }^{11}$. At this juncture, to make the policies and programmes optimally functional and inclusive every state has an important role to play. The identification of the PwDs is a responsibility of the healthcare department of the respective states in that term.

Deprivation observed by the PwDs is well marked though inadequately measured in Indian context. The backward socio-economic groups are known to experience a selection bias in the incidence of disability ${ }^{12}$. It explains that the deprived population are subjected to disability quite often, and it impacted in profound manner. PwDs are biologically disadvantageous, they are often neglected in social policy and public life ${ }^{13}$. Moreover, PwDs are also recognized to be most deprived among all backward groups of population ${ }^{6}$. The 
deprivation is known to be multi-dimensional in nature. In every aspects of development such as education, employment, health and others, it is often found that PwDs are facing extreme exclusion among other marginalized groups in the society. That led to indicate the inclusive agendas in the sustainable development goals by the actors of development at global level. Low awareness, poor nutritional outcome, poor access to physical infrastructure and basic resources are crucial to highlight the pattern of exclusion experienced by PwDs ${ }^{14}$. Social and political exclusion often degrades the health outcomes and wellbeing of the PwDs ${ }^{15}$. It suggests that a vicious cycle of deprivation may continue until a proper identification is done to target these sections of population. The effectiveness of disability centric programmes can hardly comprehend the underrecognition of PwDs. Since exclusion faced by the PwDs might vary across the types of disability they are suffering from; hence, a large set of condition can arise due to circumstances and life chances associated with different types of disability. For instance, intellectual disabilities are subjected to higher exclusion and discrimination along with the fact that identification of those population can be heavily compromised with respect to the population who suffered from physical disabilities only. Many physical only disability is also associated with the mental disability causes a double dilemma in whole circumstances. Proper identification of such complexities through a certain scale become challenge to the policymaker. A proper identification would give a proper measurement for the burden of disability. Consequently, it is also a matter of argument that at which age a person is suffering from disabling conditions and what would be probable resultant implications or significance at the household level can define the significance of disability. An occurrence of disability at old age may be subjected to less priority due to an expected higher incidence of disability and morbidity at later ages, and decline in the economic value of that person. Moreover, females and children would remain out of ambit of identification, which is associated with the fact of inherent deprivation and marginalization faced by that particular population in the society ${ }^{16-18}$.

Motivation to identify the disability remains to be poor and biased. Role played by the individual as an economic agent in the household and socio-economic agent in the society can also be explained while discussing on who is getting identified. It is necessary to mention that the disability is related to stigma and deprivation. In certain mental or intellectual disabilities, which are not viewed as physical limitation, stigma remains to be a concern over privacy for registering for a disability certificate. Many prefer to avoid the issues of disability at the cost of not accessing disability benefits, that helps them to evade the social shame ${ }^{19}$. Therefore, cultural and socio-economic justification for identifying the PwDs is also an important facet for factorizing the underlying gap in disability identification. In this backdrop, understanding the identification of the PwDs is utmost important in relation to demographic and socio-economic factors. Though several studies examined the extent, variation, and pattern of disability, no attempt has been made to understand the extent and variation of unidentified disability in India. The state-wise differences and underlying reasons of such poor identification of disability is needed to be captured to evoke about the functioning of the existing programmes and policies dedicated towards PwDs.

\section{Data And Method}

The unit data from survey of persons with disabilities in India, schedule 26.0 of the 76th round conducted by the National Sample Survey organization (NSSO) used in the analyses. The $76^{\text {th }}$ round of the nationally representative disability surveys conducted after a gap of 16 years (2002) and is the only reliable nationally 
representative data source on disability in India. The $76^{\text {th }}$ round (26.0) covered 5,76,569 individuals from $1,18,152$ households across all states and union territories of India. A total of 1,06,894 disabled individual are included in the analysis. The NSS survey was administered to households with at least one disabled member in 2018. A stratified two-stage design was adopted for the 76th round survey. In this schedule, a person is considered to have a disability if he or she has restrictions or a lack of abilities to perform an activity in the manner or within the range considered normal for a human being. Age, sex, education, religion social groups, and marital status of and cause of disability were collected for each member. Disabled were classified into any of the seven types of disability namely, locomotor, visual, hearing, speech, mental retardation, mental illness, and other disabilities. The classification of the type of disability is as per Rights of Person with Disability Act ${ }^{1}$ (RPWD, 2018) ${ }^{1}$ and the working definition of each of the disability is given in footnote. Persons with more than one disability type are considered as having multiple disabilities. The survey had asked a direct question on self-reported disability. If a person reported disability, subsequently the availability of disability certificate was asked and labelled as yes and no. A disability certificate entitled individuals to avail multiple benefits on education, employment, health care and many other social welfare programme of national and state government in India.

\section{Method:}

Outcome variable: Unidentified disabled is the main outcome variable in the analyses. It is defined as the PwDs don't have the disability certificate.

Independent variables: the set of independent variable used in study are age of the PwDs, gender (males and females), level of education (no education, primary, secondary, and above), Monthly per capita expenditure (MPCE) quintile (poorest, poor, middle, rich, and richest), religions (Hindu, Muslim, and others), social groups (ST, SC, OBC, and other), marital status (never married, currently married, and others). Economic status of PwDs was measured using the monthly per capita consumer expenditure (MPCE in Indian National Rupees). MPCE was computed by dividing the household's usual monthly expenditure by the household size (total number of individuals in the household).

\section{Statistical Methods:}

Descriptive statistics and bivariate analyses and a set of logistic regression are is used to examine the variation in overall disability certificate and among the different type of disability in India. The analyses have been carried out for all and specific type of disability.

The regression equation in its general form is given as

$Y_{i}=a+\beta_{\text {1age group }}+\beta_{2 \text { sex }}+\beta_{\text {3residence }}+\beta_{4 \text { education }}+\beta_{5 \text { MPCE quintile }}+\beta_{\text {6religion }}+\beta_{7 \text { social group }}+\beta_{8 \text { marital status }}+\varepsilon_{i}$

Where, $Y_{i}$ is the type of disability (outcome variable) and $\beta^{\prime}$ s are the regression coefficients of independent variables such as age, sex, residence, MPCE quintile, education, religion, social group and marital status. $\varepsilon_{\mathrm{i}}$ is the error term in the regression model. 
${ }^{1}$ Locomotor (Acid attack victims, Leprosy cured person, Polio, Cerebral palsy Dwarism, Muscular dystrophy, other locomotor disability. Visual disability (Blindness Low vision) Hearing Disability (Hearing Disability) Speech disability (Speech and language disability) Mental retardation/Intellectual disability (Specic learning disabilities Autism Spectrum Disorder, Other mental retardation/intellectual disability Mental illness (Mental Illness) Other Disabilities (a) Chronic neurological conditions (i) Parkinson's disease (ii) Multiple Sclerosis (iii) Other Chronic neurological conditions (b) Blood Disorder (i) Thalassemia (ii) Haemophilia (iii) Sickle cell disease. Multiple Disabilities More than one of the above specified disabilities including deafness or blindness

\section{Results}

Table 1 shows the sample profile of the surveyed population in India. The average household size was 4.3 and about 27 percent of population were illiterate. Sex ratio (number of females per 1000 male) was 929, while the median age was 27 years. About $28 \%$ population were SC/ST and $30.4 \%$ population were living in urban areas. The monthly per capita consumption expenditure (MPCE) was 2297 rupees. The disability rate (per 100,000 population) in India was 2,184 and multiple disability rate was 1,651 per 100,000 population. The pattern of disability rate varies by types of disability in India. It is highest for locomotor disability (1353) followed by hearing disability (296), and visual disability (234). The disability rate was lowest for mental illness (131) and all other disabilities (55). Among all those who were disabled, $56.2 \%$ had locomotor disability, $10.1 \%$ had hearing impairment, $9.7 \%$ had visual, $8.4 \%$ speech, $7.1 \%$ mental retardation and $6 \%$ had mental illness. 
Table 1

Sample profile of persons with disabilities in India, 2018

\begin{tabular}{|ll|}
\hline Variables & N or \% \\
\hline Total Population Covered & $5,76,569$ \\
\hline Number of households & $1,18,151$ \\
\hline Sex ratio (Number of females per 1000 male) & 929 \\
\hline Average household size & 4.3 \\
\hline Percent Urban & 30.4 \\
\hline Percent SC/ST & 27.71 \\
\hline Median Age & 27 \\
\hline Education Attainment in percent (in percentage) & \\
\hline Illiterate & 26.99 \\
\hline Up to Primary & 29.11 \\
\hline Middle/Secody & 26.23 \\
\hline Higher Secondary \& above & 17.67 \\
\hline Monthly per capita consumption expenditure (in Rupees) & 2297 \\
\hline Number of disability cases & $1,06,894$ \\
\hline Percent distribution of disabled population by type of disability (in percentage) & \\
\hline Locomotor disability & 56.2 \\
\hline Visual disability & 29.8 \\
\hline Hearing disability & 9.7 \\
\hline Speech disability & 10.1 \\
\hline Mental retardation & 8.4 \\
\hline Mental illness & 7.1 \\
\hline Other disability & 6 \\
\hline PwDs have disability certificate (in percentage) & 2.5 \\
\hline Rural area & 30.8 \\
\hline Urban area & 29.1 \\
\hline Sex (in percentage) & 26.8 \\
\hline Male & \\
\hline Female & \\
\hline
\end{tabular}


Figure 1, shows the percent distribution of having disability certificate by type of disability among disabled in India. Among persons with hearing disabilities, only $12 \%$ have disability certificate compared to $18 \%$ among mental illness. About $25 \%$ visual disabled had a certificate. Figure 2 shows the disabled person with and without disability certificate by educational level in India. A disabled person with a lower education level had less likely to have a disability certificate compare to one with higher educational level. Among those who had no education, only $24 \%$ had a disability certificate compare to $46 \%$ among those who had higher education.

Table 2 shows the possession of disability certificate among disabled by socioeconomic characteristics in India. Among females with any disability $76 \%$ do not have disability certificate compare to the $67.6 \%$ among males. The pattern is same for each and every type of disability. Gender differential in availability of disability certificate are large in case of locomotor disability. In the locomotor disability, $76 \%$ of disabled females do not have disability certificate compare to $65 \%$ among males. PwDs living in the rural areas have higher percentage share of disability certificate compare to those living in urban areas. Rural and urban differential are large in the availability of disability certificate among person with mental retardation. Availability of disability certificates among disabled also differ by age-groups. In the younger age group (6-10 years) $66 \%$ in locomotor disability do not have a disability certificate. Results show that availability of disability certificate differ by the level of education. Among illiterate category, $80 \%$ of visual disabled don't have the disability certificate compare to $53 \%$ in higher education. In the poorest MPCE quintiles and persons with hearing disabilities, $88 \%$ did not had a disability certificate compared to $87 \%$ among mental illness. Differentials among religious subgroups in access to disability certificate is large. About $91 \%$ of PwDs among ST caste groups person with hearing disability do not have disability certificate. 
Table 2

Disability certificate among disabled person by socioeconomic status in India, 2018

$\begin{array}{llllll}\begin{array}{l}\text { Any } \\ \text { disability }\end{array} & \text { Locomotor Visual Hearing Speech } & \begin{array}{l}\text { Mental } \\ \text { Retardation }\end{array} & \begin{array}{l}\text { Mental } \\ \text { illness }\end{array} & \text { Others } \\ \end{array}$

Sex

\begin{tabular}{|c|c|c|c|c|c|c|c|c|}
\hline Male & 67.6 & 65.1 & 70.3 & 86.5 & 62.7 & 52.9 & 80.6 & 79.1 \\
\hline Female & 76.1 & 75.8 & 81.0 & 90.1 & 61.0 & 52.4 & 82.6 & 82.0 \\
\hline \multicolumn{9}{|l|}{ Residence } \\
\hline Rural & 71.4 & 69.1 & 76.2 & 88.3 & 63.2 & 55.8 & 82.1 & 78.8 \\
\hline Urban & 70.4 & 70.5 & 73.7 & 88.1 & 58.5 & 45.5 & 79.7 & 82.8 \\
\hline \multicolumn{9}{|l|}{ Age group } \\
\hline $0-5$ & 88.1 & 90.4 & 84.8 & 87.2 & 88.8 & 81.2 & 89.4 & 89.2 \\
\hline $6-10$ & 68.1 & 66.7 & 65.8 & 79.2 & 73.2 & 58.6 & 73.5 & 78.7 \\
\hline $11-20$ & 55.1 & 53.0 & 53.0 & 66.7 & 57.9 & 48.1 & 69.0 & 68.8 \\
\hline $21-30$ & 49.3 & 45.4 & 40.5 & 78.2 & 44.8 & 43.7 & 76.3 & 66.8 \\
\hline $31-40$ & 55.0 & 49.6 & 55.7 & 78.5 & 51.4 & 48.1 & 81.0 & 77.7 \\
\hline $41-50$ & 66.5 & 62.4 & 66.9 & 84.0 & 59.3 & 60.1 & 85.1 & 78.0 \\
\hline $51-60$ & 78.3 & 77.1 & 77.0 & 87.8 & 62.6 & 69.8 & 87.5 & 89.2 \\
\hline $61-70$ & 86.7 & 85.9 & 86.7 & 91.5 & 76.8 & 71.2 & 90.2 & 89.9 \\
\hline $70+$ & 94.0 & 94.2 & 92.9 & 95.3 & 85.6 & 76.6 & 94.8 & 93.1 \\
\hline \multicolumn{9}{|l|}{ Education } \\
\hline Illiterate & 77.6 & 80.8 & 79.9 & 91.6 & 63.9 & 53.8 & 79.6 & 79.8 \\
\hline Primary & 70.5 & 68.9 & 74.6 & 86.4 & 62.5 & 51.3 & 83.1 & 85.0 \\
\hline Secondary & 62.7 & 58.7 & 65.7 & 82.8 & 55.7 & 47.0 & 82.7 & 80.2 \\
\hline Higher & 54.7 & 49.9 & 54.0 & 76.6 & 56.3 & 53.5 & 86.0 & 72.4 \\
\hline \multicolumn{9}{|c|}{ MPCE quintile } \\
\hline Poorest & 73.5 & 71.2 & 75.5 & 88.2 & 67.7 & 63.6 & 87.6 & 83.2 \\
\hline Poor & 72.1 & 70.2 & 75.7 & 90.7 & 61.6 & 58.0 & 80.6 & 84.4 \\
\hline Middle & 70.5 & 67.4 & 76.7 & 89.1 & 62.7 & 55.1 & 82.3 & 83.0 \\
\hline Rich & 70.1 & 68.4 & 75.2 & 87.5 & 59.2 & 48.3 & 80.4 & 79.4 \\
\hline Richest & 70.6 & 70.5 & 74.9 & 86.8 & 59.3 & 44.2 & 78.4 & 76.4 \\
\hline Religion & & & & & & & & \\
\hline
\end{tabular}




\begin{tabular}{|lllllllll|}
\hline & $\begin{array}{l}\text { Any } \\
\text { disability }\end{array}$ & Locomotor & Visual & Hearing & Speech & $\begin{array}{l}\text { Mental } \\
\text { Retardation }\end{array}$ & $\begin{array}{c}\text { Mental } \\
\text { illness }\end{array}$ & Others \\
\hline Hindu & 70.9 & 69.1 & 75.3 & 88.6 & 61.5 & 52.5 & 80.7 & 80.2 \\
\hline Muslim & 70.8 & 68.5 & 76.0 & 88.2 & 63.4 & 57.4 & 83.6 & 81.2 \\
\hline Other & 75.2 & 77.7 & 79.2 & 82.5 & 64.6 & 42.2 & 84.1 & 79.8 \\
\hline Social groups & & & & & & & & \\
\hline ST & 74.8 & 73.0 & 79.7 & 91.2 & 67.0 & 58.2 & 83.6 & 74.6 \\
\hline SC & 70.1 & 68.6 & 75.4 & 86.3 & 62.6 & 57.8 & 83.7 & 81.8 \\
\hline OBC & 70.2 & 68.0 & 75.9 & 88.4 & 60.9 & 52.2 & 81.1 & 80.8 \\
\hline Other & 71.7 & 71.7 & 73.5 & 88.3 & 61.4 & 48.5 & 79.8 & 81.2 \\
\hline Marital status & & & & & & & & \\
\hline Married & 55.4 & 51.5 & 50.3 & 69.2 & 60.3 & 49.2 & 71.7 & 71.1 \\
\hline $\begin{array}{l}\text { Currently } \\
\text { married }\end{array}$ & 74.1 & 70.5 & 77.9 & 88.5 & 63.5 & 77.2 & 90.2 & 84.9 \\
\hline \begin{tabular}{l} 
Others \\
\hline
\end{tabular} & 88.5 & 62.5 & 59.0 & 81.4 & 54.1 & 69.6 & 86.1 & 80.3 \\
\hline
\end{tabular}

Table 3 shows the disability certificates among disabled persons in state of India by types of disability. Availability of disability certificates among PwDs largely differ in the states of India. In the state of Pondicherry, 44.5\% PwDs don't have a disability certificate followed by the Jammu and Kashmir (47\%), and Telangana (49\%). Around $89 \%$ PwDs in Himachal Pradesh don't have any disability certificate compared with $85 \%$ in Assam, and $84 \%$ in Mizoram. The availability of disability certificates among PwDs varies by type of disability across states of India. In state of Arunachal Pradesh, among persons with hearing disabilities, $97 \%$ of don't have a disability certificate followed by $98 \%$ in mental illness and $88 \%$ in mental retardation. $95 \%$ person with hearing disability don't have disability certificate. In state of Orissa, $71 \%$ of any disabled people don't have a disability certificate, while among disabled $83 \%$ of people with hearing disabilities don't have a disability certificate. In Karnataka, $59 \%$ of disabled people don't have a disability certificate. Among the types of disability, $82 \%$ of visual disabled don't have a disability certificate followed by $62 \%$ of hearing disability. Karnataka is one of the states where disability certificate largely varies by the types of disability. States with the lower percent of disability certificate in India are represented by Pondicherry followed by $47 \%$ in Jammu and Kashmir and $50 \%$ in Telangana. In these states, disability certificates also differ by type of disability. In the state of Pondicherry $64 \%$ of hearing disabled have disability certificate followed by $47 \%$ in locomotor disability and $40 \%$ in visual disability. 
Table 3

Description of the disability certificate across states among disabled in India, 2018

\begin{tabular}{|c|c|c|c|c|c|c|c|c|}
\hline State & $\begin{array}{l}\text { Any } \\
\text { disability }\end{array}$ & Locomotor & Visual & Hearing & Speech & $\begin{array}{l}\text { Mental } \\
\text { retardation }\end{array}$ & $\begin{array}{l}\text { Mental } \\
\text { illness }\end{array}$ & Others \\
\hline $\begin{array}{l}\text { Arunachal } \\
\text { Pradesh }\end{array}$ & 89.3 & 87.4 & 88.9 & 97.2 & 76.2 & 98.2 & 88.2 & 99.9 \\
\hline Assam & 83.5 & 82.1 & 90.7 & 92.8 & 71.6 & 64.2 & 83.8 & 86.6 \\
\hline Mizoram & 83.4 & 73 & 91.7 & 88.3 & 84.5 & 80.1 & 91.5 & 85.6 \\
\hline Punjab & 83.2 & 84.3 & 88.3 & 93.4 & 77.7 & 56.2 & 85.7 & 84.1 \\
\hline Manipur & 80.7 & 79.9 & 84.6 & 87.6 & 76.3 & 72.9 & 82.8 & 84 \\
\hline Uttar Pradesh & 80.3 & 75.2 & 85.4 & 97 & 81.7 & 86.6 & 91.5 & 87.7 \\
\hline Nagaland & 78.9 & 82.9 & 85.9 & 90 & 63.4 & 58.7 & 60.2 & 89.2 \\
\hline Haryana & 78.4 & 79.7 & 76.9 & 91.3 & 72.8 & 59 & 79.9 & 63.8 \\
\hline Sikkim & 77.1 & 76.2 & 61.1 & 92.4 & 76.6 & 69.3 & 93.1 & 100 \\
\hline Daman \& Diu & 76.8 & 74.7 & 100 & 100 & 88.7 & 45.4 & 87.4 & 100 \\
\hline Rajasthan & 75.6 & 69 & 89 & 95.5 & 78.6 & 69 & 86.4 & 79.8 \\
\hline Chhattisgarh & 74.6 & 69.8 & 79.2 & 93 & 73.4 & 54.2 & 93.9 & 96.5 \\
\hline Maharashtra & 73.3 & 73.9 & 70.7 & 85.6 & 61.8 & 49.7 & 84.1 & 73.3 \\
\hline Chandigarh & 73.1 & 75.6 & 0 & 100 & 62.6 & 41.4 & 100 & 96.8 \\
\hline West Bengal & 72.8 & 72.4 & 71.8 & 89.5 & 57 & 53.9 & 87.9 & 86 \\
\hline Orissa & 71.5 & 72.9 & 71.5 & 82.8 & 54 & 36.8 & 75.9 & 94.2 \\
\hline Uttarakhand & 71.1 & 59.3 & 88 & 90.8 & 80.3 & 63.5 & 70.6 & 86.1 \\
\hline $\begin{array}{l}\text { Madhya } \\
\text { Pradesh }\end{array}$ & 71.1 & 67.5 & 73.2 & 94.8 & 64.5 & 63 & 85.3 & 81.7 \\
\hline Jharkhand & 69.7 & 64.3 & 74.6 & 89 & 62.4 & 69.4 & 84.2 & 91.8 \\
\hline Gujarat & 68.9 & 69.8 & 70.3 & 91.8 & 69.4 & 44.9 & 83.9 & 52.4 \\
\hline Delhi & 67.3 & 63.9 & 54.4 & 87.6 & 65.1 & 66.7 & 83.6 & 90.2 \\
\hline Goa & 66.4 & 64.7 & 80.3 & 95.6 & 17 & 24 & 93.8 & 100 \\
\hline Bihar & 66.1 & 61.9 & 72.4 & 86.1 & 68.9 & 72.4 & 81.1 & 50.9 \\
\hline $\begin{array}{l}\text { Dadra \& } \\
\text { Nagar }\end{array}$ & 65.4 & 73.4 & 57.2 & 57.7 & 61.4 & 62.7 & 100 & 9.5 \\
\hline Tamil Nadu & 64.6 & 65.6 & 73.1 & 85.5 & 49.3 & 24.8 & 73.8 & 71.9 \\
\hline Kerala & 63.4 & 65.5 & 76.6 & 78.5 & 45.4 & 17.7 & 73.7 & 83.6 \\
\hline
\end{tabular}




\begin{tabular}{|lcccccccc|}
$\begin{array}{l}\text { Andhra } \\
\text { Pradesh }\end{array}$ & 62.4 & 63.8 & 65.5 & 83.7 & 38.1 & 22.9 & 74.7 & 81.8 \\
\hline $\begin{array}{l}\text { Himachal } \\
\text { Pradesh }\end{array}$ & 61.7 & 59.9 & 63.8 & 76.8 & 54.2 & 44.9 & 79.1 & 100 \\
\hline Meghalaya & 60.3 & 58.7 & 67 & 73.6 & 53.7 & 50.7 & 51.2 & 41.1 \\
\hline Karnataka & 59.1 & 58.2 & 68.4 & 82.8 & 41.9 & 30.8 & 44.4 & 57.5 \\
\hline Lakshadweep & 58.4 & 59 & 60.6 & 72.7 & 48.9 & 35.3 & 84.7 & 0 \\
\hline $\begin{array}{l}\text { Andaman \& } \\
\text { Nicobar }\end{array}$ & 57.4 & 65.4 & 62 & 53.1 & 62.3 & 0.8 & 49.3 & 74.8 \\
\hline \begin{tabular}{l} 
Tripura \\
\hline Telangana
\end{tabular} & 49.5 & 48.9 & 53.1 & 69.6 & 31.6 & 48.8 & 64 & 75.8 \\
\hline $\begin{array}{l}\text { Jammu \& } \\
\text { Kashmir }\end{array}$ & 47.2 & 44.7 & 40.1 & 65.4 & 35 & 58.9 & 56.5 & 72 \\
\hline Pondicherry & 44.5 & 46.7 & 39.9 & 64 & 17.9 & 29.3 & 22.2 & 0 \\
\hline
\end{tabular}

Table 4, shows the unadjusted and adjusted odds ratio of disability certificate among disabled, with socioeconomic characteristics in India. Unadjusted odds ratio shows that person with hearing disability (OR = $0.30 \mathrm{Cl} 0.303-0.304)$ are less likely to hold a disability certificate compare to locomotor disability followed by mental illness disability $(\mathrm{OR}=0.52 \mathrm{Cl} 0.5190520)$, other disability $(0.56 \mathrm{Cl} 0.5590 .560)$. Results shows that person with mental retardation is two times more likely to hold the disability certificate $(2.05 \mathrm{Cl} 2.0462 .047)$. Adjusted odds ratio with socioeconomic characteristics shows the variation in availing of disability certificates among disabled and with socioeconomic status. Odds ratio of availing disability certificate varies across age groups among disabled person. Disabled in the age group of 21-30 were 9 times more likely to have disability certificate in compare to reference age group. In early age group of 5-10 years, chances of disability certificates among locomotor disabled are higher in compare to the reference group. Odds ratio of disability certificate was higher among persons living in urban area compare to rural area. Disabled females are less likely to have a disability certificate compare to their male counterparts. Economic status and disability certificates are positively associated as the economic condition is improving, percentage of having disability certificates is also improving. Muslims and others disabled are less likely to have disability certificates compare to Hindu disabled. In social groups, the OBC category has a higher likelihood of accessing a disability certificate. 
Table 4

unadjusted and adjusted odds ratio of access to disability certificate among PwDs in India, 2018

\begin{tabular}{|c|c|c|c|c|}
\hline \multirow{2}{*}{$\begin{array}{l}\text { Variable } \\
\text { Type Disability }\end{array}$} & \multicolumn{2}{|l|}{ Unadjusted } & \multicolumn{2}{|l|}{ Adjusted } \\
\hline & Odds ratio & $95 \% \mathrm{Cl}$ & Odds ratio & $95 \% \mathrm{Cl}$ \\
\hline \multicolumn{5}{|l|}{ Locomotor $B$} \\
\hline Visual & $0.74 * \star \star$ & $0.736-0.737$ & $1.1 * \star \star$ & $0.997-0.998$ \\
\hline Hearing & $0.30 * \star \star$ & $0.303-0.304$ & $0.46 * \star \star *$ & $0.458-0.458$ \\
\hline Speech & $1.40 * \star \star$ & $1.399-1.400$ & $1.02 * \star \star *$ & $1.020-1.021$ \\
\hline Mental Retardation & $2.05^{\star \star \star}$ & $2.046-2.047$ & $1.14^{\star \star \star}$ & $1.139-1.140$ \\
\hline Mental illness & $0.52 * \star \star$ & $0.519-0.520$ & $0.32 * \star \star$ & $0.325-0.325$ \\
\hline Others & $0.56^{\star \star \star}$ & $0.559-0.560$ & $0.44^{\star \star}$ & $0.442-0.442$ \\
\hline \multicolumn{5}{|l|}{ Age group } \\
\hline \multicolumn{5}{|l|}{$1-5 \AA$} \\
\hline $6-10$ & & & $3.48 \star \star$ & $3.476-3.482$ \\
\hline $10-20$ & & & $5.79 \star \star$ & $5.788-5.798$ \\
\hline $21-30$ & & & $9.58 * \star$ & $9.568-9.584$ \\
\hline $31-40$ & & & $10.44^{\star \star \star}$ & $10.434-10.451$ \\
\hline $41-50$ & & & $7.25^{\star \star \star}$ & $7.243-7.255$ \\
\hline $51-60$ & & & $4.44^{\star \star \star}$ & $4.433-4.44$ \\
\hline $61-70$ & & & $2.64^{\star \star}$ & $2.642-2.646$ \\
\hline $71+$ & & & $1.18^{\star}$ & $1.182-1.185$ \\
\hline \multicolumn{5}{|l|}{ Residence } \\
\hline \multicolumn{5}{|l|}{ Rural® } \\
\hline Urban & & & $1.05^{\star \star}$ & $1.050-1.05$ \\
\hline \multicolumn{5}{|l|}{ Sex } \\
\hline \multicolumn{5}{|l|}{ Male® } \\
\hline Female & & & $0.82^{\star \star}$ & $0.820-0.82$ \\
\hline \multicolumn{5}{|l|}{ Education } \\
\hline \multicolumn{5}{|l|}{ Illiterate ${ }^{\circledR}$} \\
\hline Up to primary & & & $1.08 * \star \star$ & $1.076-1.076$ \\
\hline$(B)=$ Reference grou & evel of sigr & icance: $* * * p<$ & $01 ; * * p<0.0$ & $;{ }^{*} p<0.10$ \\
\hline
\end{tabular}




\begin{tabular}{|c|c|c|c|}
\hline Variable & Unadjusted & \multicolumn{2}{|c|}{ Adjusted } \\
\hline Middle/secondary & & 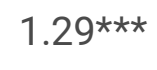 & $1.289-1.29$ \\
\hline Higher & & $1.72^{\star \star \star}$ & $1.717-1.719$ \\
\hline \multicolumn{4}{|l|}{ MPCE Quintile } \\
\hline \multicolumn{4}{|l|}{ Poorest ${ }^{\circledR}$} \\
\hline Poor & & $1.1^{\star \star \star}$ & $1.098-1.099$ \\
\hline Middle & & $1.21^{\star \star}$ & $1.208-1.209$ \\
\hline Rich & & $1.28^{* *}$ & $1.280-1.28$ \\
\hline Richest & & $1.36^{\star \star \star}$ & $1.362-1.363$ \\
\hline \multicolumn{4}{|l|}{ Religion } \\
\hline \multicolumn{4}{|l|}{ Hindu $\circledast$} \\
\hline Muslim & & $0.9 * \star \star$ & $0.904-0.904$ \\
\hline Others & & $0.84^{\star}$ & $0.837-0.838$ \\
\hline \multicolumn{4}{|l|}{ Social Groups } \\
\hline \multicolumn{4}{|l|}{ ST ${ }^{\circledR}$} \\
\hline SC & & $1.14^{\star *}$ & $1.135-1.136$ \\
\hline $\mathrm{OBC}$ & & $1.23^{\star *}$ & $1.226-1.227$ \\
\hline Others & & $1.12^{\star}$ & $1.122-1.122$ \\
\hline \multicolumn{4}{|l|}{ Marital Status } \\
\hline \multicolumn{4}{|l|}{ Married $\circledast$} \\
\hline Currently married & & $0.45^{\star}$ & $0.445-0.445$ \\
\hline Others & & $0.37^{\star \star *}$ & $0.370-0.37$ \\
\hline${ }^{\circledR}=$ Reference grou & evel of sign & $01 ; * * p$ & $; * p<0.10$ \\
\hline
\end{tabular}

Table 5a, shows the odds of disability certificate in locomotor, visual and hearing disability with selected socioeconomic characteristics. Results shows that in the age group 21-30 years, the odds of disability certificate $(\mathrm{OR}=11.70 \mathrm{Cl} 11689-11720)$ is higher. The odds of disability certificate increases with increasing age groups but after age group of 51-60 year, the odds ratio decreases. Gender differentials for accessing a disability certificates among disabled are favourable for males. The chances of having a disability certificate differ largely in different type of disability by the level of education. Among illiterate, disability certificate is lower in compare to primary educational level. While in secondary and higher education groups the probability of having a disability certificates is higher than primary and illiterate. Availability of disability certificate differs by MPCE quintiles, poorest have the lower chances of having disability certificate in compare to the richer and 
richest category. In the marital status, married disabled persons has a higher probability of having disability certificates. Odds ratio of disability certificate among person with visual disability are higher in rural (OR 1.03 $\mathrm{Cl} 1.033-1.035)$ areas compared to urban area. Females with disability less likely to hold disability certificates for visual disability than males with disability. Increase in the level of education increases the probability of holding a disability certificate among PwDs. In higher educational category, the odds ratio for accessing a disability certificate is higher $(\mathrm{OR}=1.28 \mathrm{Cl} 1.276-1.280)$ than reference category. Person with visual disability in the poorest category $(\mathrm{OR}=0.98 \mathrm{Cl} 0.983-986)$ are less likely to hold the disability certificate compared to the richest sub-groups $(\mathrm{OR}=1.19 \mathrm{Cl} 1.193-1.196)$. Among the person with visually disabled, other caste group has a higher probability of holding disability certificates compare to SC and ST caste groups. A person with hearing disability in age group of 31-40 years, a higher likelihood to hold disability certificate compare to the reference group has been observed. In speech disability, odds ratio of disability certificate followed the same pattern as locomotor disability. In the mental retardation, odds ratio of disability certificate followed the same pattern across age groups. In urban area, odds ratios show (1.35 Cl 1.345-1.348) more likely to hold disability certificate for disabled. A person with mental illness in age group of 31-40 years is more likely to hold disability certificate compare to its reference group. In Mental illness, odds ratio of having disability certificate followed same pattern as mental retardation. Person with mental illness are more likely to hold disability certificate in urban area compare to rural area. 
Table 5a

Odds ratio of disability certificate among types of disability by socioeconomic status in India, 2018

\begin{tabular}{|c|c|c|c|c|c|c|}
\hline Variable & \multicolumn{2}{|c|}{ Locomotor Disability } & \multicolumn{2}{|c|}{ Visual Disability } & \multicolumn{2}{|c|}{ Hearing Disability } \\
\hline Age group & \multicolumn{2}{|c|}{ Odd Ratio 95\% Cl } & \multicolumn{2}{|c|}{ Odd Ratio 95\% Cl } & \multicolumn{2}{|c|}{ Odd Ratio 95\% Cl } \\
\hline \multicolumn{7}{|l|}{$1-5 \AA$} \\
\hline $6-10$ & $4.12^{\star \star \star}$ & $4.11-4.12$ & $3.01 * \star \star$ & $3.00-3.02$ & $1.67 * * *$ & $1.66-1.68$ \\
\hline $11-20$ & $6.33^{\star \star \star}$ & $6.32-6.34$ & $4.94 * \star \star$ & $4.93-4.96$ & $2.82^{\star \star}$ & $2.80-2.83$ \\
\hline $21-30$ & 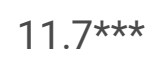 & $11.69-11.72$ & $12.14^{\star \star \star}$ & $12.10-12.18$ & $2.78 * \star \star$ & $2.76-2.79$ \\
\hline $31-40$ & $13.77 * \star$ & $13.76-13.79$ & $10.85^{\star \star \star}$ & $10.82-10.89$ & $4.49 *$ & $4.46-4.51$ \\
\hline $41-50$ & $9.36 * \star \star$ & $9.35-9.38$ & $7.45^{\star \star}$ & $7.43-7.48$ & $3.36 * \star$ & $3.34-3.38$ \\
\hline $51-60$ & 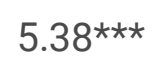 & $5.38-5.39$ & $5.08 * \star$ & $5.07-5.1$ & $2.63^{\star \star}$ & $2.62-2.65$ \\
\hline $61-70$ & $3.17 \star \star$ & $3.17-3.18$ & $2.75^{\star \star}$ & $2.74-2.76$ & $1.84^{\star \star}$ & $1.83-1.85$ \\
\hline $71+$ & $1.26 * \star \star$ & $1.26-1.26$ & $1.41^{\star \star}$ & $1.40-1.41$ & $0.93 *$ & $0.93-0.94$ \\
\hline
\end{tabular}

\section{Residence}

Ruralß

Urban

$0.93^{\star *}$

$0.93-0.93$

$1.03 * \star$

1.03-1.04

$1.02 * \star \star$

$1.02-1.02$

\section{Sex}

Male ${ }^{\circledR}$

Female

$0.77 * * *$

$0.77-0.78$

$0.63^{\star \star \star}$

$0.63-0.63$

$0.82^{\star \star \star} \quad 0.82-0.82$

\section{Education}

illiterate $®$

\begin{tabular}{|c|c|c|c|c|c|c|}
\hline Up to primary & $1.23^{\star * *}$ & $1.23-1.23$ & $0.89 * \star \star$ & $0.89-0.9$ & $1.16^{\star \star \star}$ & $1.16-1.16$ \\
\hline Middle/secondary & $1.54^{\star \star \star}$ & $1.54-1.54$ & $1.05^{\star \star \star}$ & $1.05-1.05$ & $1.26 * * *$ & $1.26-1.27$ \\
\hline Higher & $2.19 * \star \star$ & $2.18-2.19$ & $1.28 * \star \star$ & $1.28-1.28$ & $2.04^{\star \star}$ & $2.04-2.04$ \\
\hline
\end{tabular}

\section{MPCE Quintile}

Poorest ${ }^{\circledR}$

\begin{tabular}{|c|c|c|c|c|c|c|}
\hline Poor & $1.07^{\star \star \star}$ & $1.07-1.07$ & $0.98 * * *$ & $0.98-0.99$ & $0.83^{\star \star \star}$ & $0.83-0.83$ \\
\hline Middle & $1.22^{\star \star \star}$ & $1.22-1.22$ & $0.95^{\star \star *}$ & $0.95-0.95$ & $1 * \star \star$ & $1.00-1$ \\
\hline Rich & $1.17^{\star \star *}$ & $1.17-1.17$ & $1.03 * * *$ & $1.03-1.03$ & $1.17 * \star \star *$ & $1.17-1.18$ \\
\hline Richest & $1.21 * \star \star *$ & $1.21-1.21$ & $1.19 * \star$ & $1.19-1.2$ & $1.29 * * \star$ & $1.29-1.3$ \\
\hline
\end{tabular}

B = Reference group; Level of significance: ${ }^{* *} p<0.01 ;{ }^{* *} p<0.05 ; * p<0.10$ 


\begin{tabular}{|c|c|c|c|c|c|c|}
\hline Variable & \multicolumn{2}{|c|}{ Locomotor Disability } & \multicolumn{2}{|c|}{ Visual Disability } & \multicolumn{2}{|c|}{ Hearing Disability } \\
\hline \multicolumn{7}{|l|}{ Religion } \\
\hline \multicolumn{7}{|l|}{ Hinduß } \\
\hline Muslim & $0.97^{\star}$ & $0.97-0.97$ & $0.82^{\star \star}$ & $0.82-0.82$ & $0.92^{\star \star}$ & $0.92-0.92$ \\
\hline Others & $0.7 *$ & $0.70-0.7$ & $0.85^{\star \star}$ & $0.85-0.85$ & 1.71 ** & $1.70-1.71$ \\
\hline \multicolumn{7}{|l|}{ Social Groups } \\
\hline \multicolumn{7}{|l|}{ ST $®$} \\
\hline SC & $1.15^{\star \star}$ & $1.15-1.15$ & $1.25^{\star \star \star}$ & $1.25-1.25$ & $1.7 * \star$ & $1.70-1.71$ \\
\hline $\mathrm{OBC}$ & $1.19 * *$ & $1.19-1.2$ & $1.36^{\star \star}$ & $1.36-1.37$ & $1.57^{\star \star}$ & $1.57-1.58$ \\
\hline Others & $1.02^{*}$ & $1.02-1.02$ & $1.49 * \star$ & $1.49-1.49$ & $1.49 * \star$ & $1.49-1.5$ \\
\hline \multicolumn{7}{|l|}{ Marital Status } \\
\hline \multicolumn{7}{|l|}{ Married $®$} \\
\hline Currently married & $0.44^{*}$ & $0.44-0.44$ & $0.31^{\star \star}$ & $0.31-0.31$ & $0.32 * \star$ & $0.32-0.32$ \\
\hline Others & 0.36 & $0.36-0.37$ & $0.28 *$ & $0.28-0.29$ & $0.27 \star$ & $0.27-0.27$ \\
\hline
\end{tabular}


Table 5b

Odds ratio of disability certificate among types of disability by socioeconomic status in India, 2018

\begin{tabular}{|c|c|c|c|c|c|c|}
\hline Variables & \multicolumn{2}{|c|}{ Speech Disability } & \multicolumn{2}{|c|}{ Mental Retardation } & \multicolumn{2}{|c|}{ Mental illness } \\
\hline Age group & \multicolumn{2}{|c|}{ Odd Ratio 95\% Cl } & \multicolumn{2}{|c|}{ Odd Ratio 95\% Cl } & \multicolumn{2}{|c|}{ Odd Ratio 95\% Cl } \\
\hline $1-5 \circledast$ & & & & & & \\
\hline $6-10$ & $2.9 * \star \star$ & $2.90-2.91$ & $3.08^{\star \star \star}$ & $3.07-3.08$ & $3.96^{\star \star \star}$ & $3.93-3.99$ \\
\hline $11-20$ & $5.82 * \star \star$ & $5.81-5.83$ & $4.75^{\star \star \star *}$ & $4.74-4.76$ & 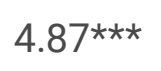 & $4.84-4.91$ \\
\hline $21-30$ & $12.68 * \star$ & $12.66-12.7$ & 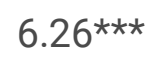 & $6.25-6.28$ & 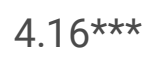 & $4.13-4.19$ \\
\hline $31-40$ & $11.5^{\star \star \star}$ & $11.47-11.52$ & $6.11^{\star \star \star *}$ & $6.10-6.12$ & $4.14^{\star \star \star}$ & $4.11-4.17$ \\
\hline $41-50$ & $8.48^{\star \star \star}$ & $8.47-8.5$ & $4.34^{\star \star \star}$ & $4.33-4.35$ & $3.45^{\star \star \star}$ & $3.43-3.48$ \\
\hline $51-60$ & $7.52^{\star \star}$ & $7.50-7.53$ & $3.41^{\star \star}$ & $3.41-3.42$ & $3.25^{\star \star}$ & $3.23-3.28$ \\
\hline $61-70$ & $4.03 *$ & $4.02-4.04$ & $3.86 * \star$ & $3.84-3.87$ & $2.52^{\star \star}$ & $2.50-2.54$ \\
\hline $71+$ & 2.17 & $2.17-2.18$ & 3.08 & $3.07-3.1$ & $1.21 * \star \star$ & $1.20-1.22$ \\
\hline
\end{tabular}

\section{Residence}

Ruralß

Urban

$1.26 * * \star \quad 1.26-1.26$

$1.53 * \star \star$

$1.53-1.54$

$1.35^{\star \star \star}$

$1.35-1.35$

\section{Sex}

Male ${ }^{\circledR}$

Female

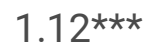

$1.12-1.13$

$1.1^{\star \star \star}$

$1.10-1.1$

$1.02^{\star \star \star}$

1.02-1.02

\section{Education}

illiterate ${ }^{\circledR}$

\begin{tabular}{|c|c|c|c|c|c|c|}
\hline Up to primary & $1.03^{\star * \star}$ & $1.03-1.04$ & $1.05^{\star \star *}$ & $1.05-1.05$ & $0.71^{\star * *}$ & $0.71-0.71$ \\
\hline Middle/secondary & $1.01^{\star \star \star}$ & $1.01-1.01$ & $1.23^{\star \star}$ & $1.23-1.23$ & $0.73^{\star \star \star}$ & $0.73-0.73$ \\
\hline Higher & $0.83^{\star \star \star}$ & $0.82-0.83$ & $1.01^{\star \star \star}$ & $1.01-1.02$ & $0.52 * \star \star$ & $0.52-0.52$ \\
\hline
\end{tabular}

Poorest ${ }^{\circledR}$

\begin{tabular}{|c|c|c|c|c|c|c|}
\hline Poor & $1.19 * \star$ & $1.19-1.19$ & $1.3^{\star \star \star}$ & $1.30-1.31$ & $1.8^{\star \star}$ & $1.80-1.8$ \\
\hline Middle & 1.17 ** & $1.17-1.17$ & $1.52^{\star \star \star}$ & $1.52-1.52$ & 1.67 ** & $1.67-1.68$ \\
\hline Rich & $1.4^{\star \star \star}$ & $1.40-1.4$ & $1.92^{\star \star \star}$ & $1.92-1.92$ & $2.06 * \star \star *$ & $2.05-2.06$ \\
\hline Richest & $1.44^{\star \star \star}$ & $1.44-1.44$ & $2.32^{\star \star}$ & $2.31-2.32$ & $2.53^{\star \star \star}$ & $2.53-2.54$ \\
\hline
\end{tabular}

(B) = Reference group; Level of significance: ${ }^{* *} p<0.01 ;{ }^{* *} p<0.05 ;{ }^{*} p<0.10$ 


\begin{tabular}{|c|c|c|c|c|c|c|}
\hline Variables & \multicolumn{2}{|c|}{ Speech Disability } & \multicolumn{2}{|c|}{ Mental Retardation } & \multicolumn{2}{|c|}{ Mental illness } \\
\hline \multicolumn{7}{|l|}{ Religion } \\
\hline \multicolumn{7}{|l|}{ Hindu $\circledast$} \\
\hline Muslim & $0.88^{\star *}$ & $0.88-0.88$ & $0.74^{\star \star}$ & $0.74-0.75$ & $0.71^{\star *}$ & $0.71-0.71$ \\
\hline Others & $0.83^{\star}$ & $0.83-0.83$ & $1.3^{\star}$ & $1.30-1.3$ & $0.75^{\star}$ & $0.75-0.75$ \\
\hline \multicolumn{7}{|l|}{ Social Groups } \\
\hline \multicolumn{7}{|l|}{ ST ${ }^{\circledR}$} \\
\hline SC & $1.15^{\star \star}$ & $1.15-1.15$ & $0.96 * \star \star$ & $0.96-0.96$ & $0.9 * \star$ & $0.89-0.9$ \\
\hline $\mathrm{OBC}$ & $1.28^{\star \star *}$ & $1.28-1.28$ & $1.21^{\star \star}$ & $1.21-1.22$ & $1.21^{\star \star *}$ & $1.21-1.21$ \\
\hline Others & $1.18^{*}$ & $1.18-1.18$ & $1.17 \star \star$ & $1.17-1.17$ & $1.22^{\star}$ & $1.22-1.23$ \\
\hline \multicolumn{7}{|l|}{ Marital Status } \\
\hline \multicolumn{7}{|l|}{ Married® } \\
\hline Currently married & $0.53^{\star \star}$ & $0.53-0.53$ & $0.26 \star \star$ & $0.26-0.26$ & $0.34 * \star$ & $0.34-0.34$ \\
\hline Others & $0.54^{\star}$ & $0.54-0.54$ & $0.34^{\star}$ & $0.34-0.34$ & 0.41 & $0.41-0.42$ \\
\hline
\end{tabular}

\section{Discussion}

The study measures the extent of non-access to the disability certificates among PwDs in India. Our study has come across three salient findings. First, about 7 in 10 PwDs do not possess a disability certificate in India, which suggests lower access to programmes and facilities available for the PwDs. In contrast, it also suggests that a share of PwDs possess a certain level of disability which is not eligible for the disability benefit. Secondly, there is a varying disparity in the access of disability certificate across types of disability, selected socio-economic categories such as, place of residence, caste, gender and education. The difference in the access to disability is also persistent across states of India reflecting the inadequacy in the healthcare and social welfare delivery system. Lastly, our study identifies that the exclusion in accessing the disability certificate is also attached to a notion of social stigma, disparity and vulnerability inherent to the PwDs with a certain type. It evokes that PwDs or their family members avoid to reveal their disability in a fear of social stigma.

To explain the gap in accessing a disability certificate it is imperative to mention here that upto a certain level of disabling conditions access to a disability certificate is not essential. In India, $40 \%$ of disability is considered as a significant disability and given a certificate. The access to disability certificate is matter of awareness, knowledge and perceived need of the individuals. Educational achievement is also related to health care access and behaviour among population ${ }^{20,21}$. A handful population with disability are not motivated enough to get a disability certificate, if their disabling conditions are minor and not affecting their daily activities in remarkable way. Identifying this section of population with disability is challenging and is not easy to consider 
under the umbrella of social welfare benefits. Further, to access a disability certificate several other documents are required such as income, caste, domicile certificate etc. Many individuals do not possess all these documents with them. To arrange the supporting documents it takes a lot of effort and time, which may feel cumbersome and hectic to the individuals with disability or their family members. This condition compromise the access to the disability certificate. Hence, the administrative procedure to identify a PwDs dampens the access in a great extent considering such conditions.

The socio-economic association to the access to certificate clearly explain that the place of residence is a biggest hurdle for accessing services by the PwDs ${ }^{22}$. In majority of the cases, disability has a higher likelihood of getting a certificate from urban areas, reflecting a lack of facility to get certificate in the urban set-ups. Besides, being female, reserved socio-economic groups, low education and poor standard of living have a lesser likelihood to get a disability certificate. This suggests that a defined vulnerability exists among PwDs. Females in general are identified later than males for the case of disability. Females with a severe forms of disability is identified more than males identified with a disability at the same time ${ }^{23}$. Socio-economic deprivation also results in one to get lesser benefits and hence, poorer performance among PwDs ${ }^{24,25}$. This is confirmed by the study findings as it shows that in compared to STs, other castes are showing a higher likelihood to access disability certificates. As our study explore the variation in access to certificates across different types of disability, it gives a clear indication that few disability has been observed a higher incidence of chronic conditions in compared to the rest. The argument on who are not getting identified lies in the complex structure of individual and social needs. It explains that necessity to get benefits for few disabling conditions prompts us to a higher access of disability certificates. The incidence of such disabling conditions if occurring at the early age groups or young adulthood shows a higher chances of registration of the policies and programmes. Disability in hearing and mental retardation are found to get least percentage share for accessing the disability certificates found in our study. For instance, it has been already documented that hearing loss may decelerate the development of speech, hence, results into a disability in speech (National Research Council of United States). Multiple disability may impede the daily activity in much more significant way. Whereas, mental retardation is associated with the other disabling conditions like, motor skill disorders, vision problems etc. These complications require a long-term treatment and rehabilitation to improve the condition. Therefore, registering to a disability certificate would give them a benefit of low cost or free treatment for long term care.

In some states in India, the primary health workers, who are catering to the need of maternal and child care services, are following and registering the children under different schemes and helping to access a disability certificate ${ }^{26}$. Besides, schools are another institute that helps to identify a mental retardation, intellectual disability, vision or hearing disabilities among children in India ${ }^{27}$. Above mentioned disabilities are more pronounced in the polity of disability and development. However, stigma attached to disability hampers the access to social services, benefits and identification on paper. Disability due to mental illness is a matter of stigma and shame. Social shame, restricted social participation and poverty for this kind of disability is well understood in the context of India ${ }^{28,29}$. Moreover, low rate and delayed age of incidence of this kind of disability might be a reason for less value attached to the access of social benefits or other services ${ }^{14}$. A lesser access to a disability certificate for mental illness is explained in our study. 
The prevalence of the access to disability certificate suggests that a significant number of states are having a low incidence. The explanation for this evidence upholds that active participation of the local health care providers for timely identification of the disability among population. States like Punjab, which shows a higher access to disability certificates, has taken an active step by the Department of Social Security and Women \& Child Development in identifying and providing a regular health check up to PwDs (https://sswcd.punjab.gov.in/en/social-security/persons-with-disabilities-pwds). Recently, various states have taken a step to conduct camps to disburse disability certificates. Despite having a provision for the disability enumeration through primary health centers or camps, many states are not active enough to implement it efficiently. Therefore, a poor identification and access to disability certificate can be observed in our study. DDRCs are one of the prime healthcare structure which are given with the responsibilities for the identification, monitoring and evaluation of disabilities at the ground level. Meagre number of functional DDRCs, which is around 31 as against proposed 300 in India (2018-19) (https://www.indiastat.com/Home/DataSearch? Keyword=district\%20disability\%20rehabilitation\%20center), suggests that disability identification and access to basic facilities like disability certificates and related information is poor in our country. The growing incidence of disability is a prime event that lurks inefficiency of public health and social welfare system. Evidently, low access to disability certificate would definitely decline the access to social benefits like disability pension, health benefits, and other development benefits. Further, resource allocation may be compromised if inadequate identification of the potential population is done due to measurement error. Therefore, it can be concluded that a bidirectional relationship exists between identification of disability and resource allocation or utilization. Our study is limited to understand the level of disability vis-à-vis access to disability certificate since it is out of the scope of study. Further studies are required to understand the disability certificate in such context. Moreover, inclusion of the different social welfare schemes or pension could bring forth a vivid picture regrading administrative and political relevance of the disability scenario in India.

\section{Conclusion}

The study aims to understand the access to disability certificate among different types of PwDs in India. It has been clearly marked that the dearth in the access to those certificates is not due to systematic failure but various social-economic dimensions are also responsible for such behaviour. Various norms under health and social welfare policies across states, which are inconducive to the PwDs might be responsible for varying access to disability certificates. As a result, participation in education, employment and other human development indicators can be compromised in a great extent. This can further suggest an inadequate identification of the PwDs. Our study gives an in-depth analysis of the pattern of identification among the PwDs through disability certificates. It is suggested that urgent steps are needed to be taken to better identification of the PwDs through an administrative tool. Hence, social support can be delivered to every PwD, and make the developmental approach more inclusive.

\section{List Of Abbreviations}

MPCE Monthly per capita expenditure

NSSO National sample survey organization 
OBC Other backward caste

PWDs Person with disabilities

RPWD Right of person with disability

SC Scheduled caste

ST Scheduled tribe

\section{Declarations}

Ethics approval and consent to participate: As the analysis is based on secondary data available in the public domain, it needs no prior approval.

Consent for publication: This manuscript is an original work and has been done by the authors, RSM, SKM, SC who all are aware of its content and approve its submission. This manuscript has not been published elsewhere in part or in entirety, and is not under consideration by another journal. All authors gave their consent for publication in International Journal for Equity in Health.

Availability of data and material: The dataset used and analysed for the current study is available in MoSPI repository, http://www.mospi.nic.in/

Competing interests: The authors declare that they do not have any competing interest.

Funding: Not applicable

Authors' contributions: Conception and design of study: RSM and SKM; analysis and interpretation of data: RSM and SKM; drafting the manuscript: RSM, SKM, SC; critical revision of the manuscript for important intellectual content: SKM, SC, RSM.

\section{References}

1. Kostanjsek N, Good A, Madden RH, et al. Counting disability: Global and national estimation. Disabil Rehabil. 2013;35(13):1065-1069. doi:10.3109/09638288.2012.720354

2. Madans JH, Loeb ME, Altman BM. Measuring disability and monitoring the un Convention on the Rights of Persons with Disabilities: The work of the Washington Group on Disability Statistics. BMC Public Health. 2011;11(SUPPL. 4). doi:10.1186/1471-2458-11-S4-S4

3. ORGI. Census of India- Data on disability. Office of the Registrar General \& Census Commissioner.

4. Jeffery R, Singal N. Measuring disability in India. Econ Polit Wkly. 2008:22-24. http://nbnresolving.de/urn:nbn:de:0168-ssoar-69620.

5. Dandona R, Pandey A, George S, Kumar GA, Dandona L. India's disability estimates: Limitations and way forward. PLoS One. 2019;14(9):1-19. doi:10.1371/journal.pone.0222159

6. WHO. World Report on Disability. Vol 91. Geneva, Switzerland; 2011. doi:10.1136/ip.2007.018143 
7. Awasthi A, Pandey CM, Dubey M, Rastogi S. Trends, prospects and deprivation index of disability in India: Evidences from census 2001 and 2011. Disabil Health J. 2017;10(2):247-256.

doi:10.1016/j.dhjo.2016.10.011

8. Mont D. Measuring disability prevalence. Soc Prot World Bank. 2007;(706):1-54.

9. Menon N, Parish SL, Rose RA. The "State" of Persons with Disabilities in India. J Hum Dev Capab. 2014;15(4):391-412. doi:10.1080/19452829.2014.938729

10. Gudlavalleti MVS, John N, Allagh K, Sagar J, Kamalakannan S. Access to health care and employment status of people with disabilities in South India, the SIDE ( South India Disability Evidence ) study. 2014:18.

11. Government of Kerala. Disability Census- 2015. Trivandrum; 2015. http://marefateadyan.nashriyat.ir/node/150.

12. Bradbury B, Abello D. Disadvantage and the prevalence of disability Socio-Economic Disadvantage and the Prevalence of Disability. 2001;(January):1-73.

13. Lamichhane K, Ballabha D, Kartika D. Analysis of Poverty between People with and without Disabilities in Nepal. Tokyo, Japan; 2014. http://repository.ri.jica.go.jp/dspace/handle/10685/252.

14. Grills N, Singh L, Pant H, et al. Access to services and barriers faced by people with disabilities: A quantitative survey. Disabil CBR Incl Dev. 2017;28(2):23-44. doi:10.5463/DCID.v28i2.615

15. Krahn GL, Walker DK, Correa-De-Araujo R. Persons with disabilities as an unrecognized health disparity population. Am J Public Health. 2015;105:S198-S206. doi:10.2105/AJPH.2014.302182

16. Ghai A. Disabled Women: An Excluded Agenda of Indian Feminism. Hypatia A J Fem Philos. 2002;17(3):49-66. doi:10.2979/hyp.2002.17.3.49

17. Vlassoff C. Gender differences in determinants and consequences of health and illness. J Heal Popul Nutr. 2007;25(1):47-61. doi:10.3329/jhpn.v25i1.674

18. UNFPA. Disability Rights, Gender, and Development-A Resource Tool for Action.; 2008.

19. Mishra NN, Parker LS, Nimgaonkar VL, Deshpande SN. Disability certificates in India: a challenge to health privacy. Indian J Med Ethics. 2012;9(1):43-45. doi:10.20529/ijme.2012.010

20. Zajacova A, Lawrence EM. The Relationship between Education and Health: Reducing Disparities Through a Contextual Approach. Annu Rev Public Health. 2018;39:273-289. doi:10.1146/annurev-publhealth031816-044628

21. Bines H, Lei P. Disability and education: The longest road to inclusion. Int J Educ Dev. 2011;31:419-424. doi:10.1016/j.ijedudev.2011.04.009

22. Gudlavalleti MVS, John N, Allagh K, et al. Access to health care and employment status of people with disabilities in South India, the SIDE (South India Disability Evidence) study. BMC Public Health. 2014;14(1):1-8. doi:10.1186/1471-2458-14-1125

23. Severance S, Howell E. On Gender Disparities in Disability Identification and Special Education Services Referral Bias: The Role of Subjective Opinion. 2017;8(2).

24. Minkler M, Fuller-Thomson E, Guralnik JM. Gradient of Disability across the Socioeconomic Spectrum in the United States. N Engl J Med. 2006;355(7):695-703. 
25. Mishra RS, Mohanty SK. Socioeconomic and health correlates disability in India Socioeconomic and health correlates disability in India. Int J Community Med Public Heal. 2021;5(2):600-610. doi:10.18203/2394-6040.ijcmph20180236

26. Nair MK, George B, Padmamohan J, et al. Developmental delay and disability among under- 5 children in a rural ICDS block. Indian Pediatr. 2009;46 Suppl.

27. Ravindran M, Pawar N, Renagappa R, Ravilla T, Khadse R. Identifying barriers to referrals in preschool-age ocular screening in Southern India. Indian J Ophthalmol. 2020;68(10):2179-2184. doi:10.4103/ijo.IJO

28. Trani J-F, Bakhshi P, Myers Tlapek S, Lopez D, Gall F. Disability and Poverty in Morocco and Tunisia: A Multidimensional Approach. J Hum Dev Capab. 2015;16(4):518-548.

doi:10.1080/19452829.2015.1091808

29. Mitra S, Posarac A, Vick B. Disability and poverty in developing countries: A multidimensional study. World Dev. 2013;41(1):1-18. doi:10.1016/j.worlddev.2012.05.024

\section{Figures}

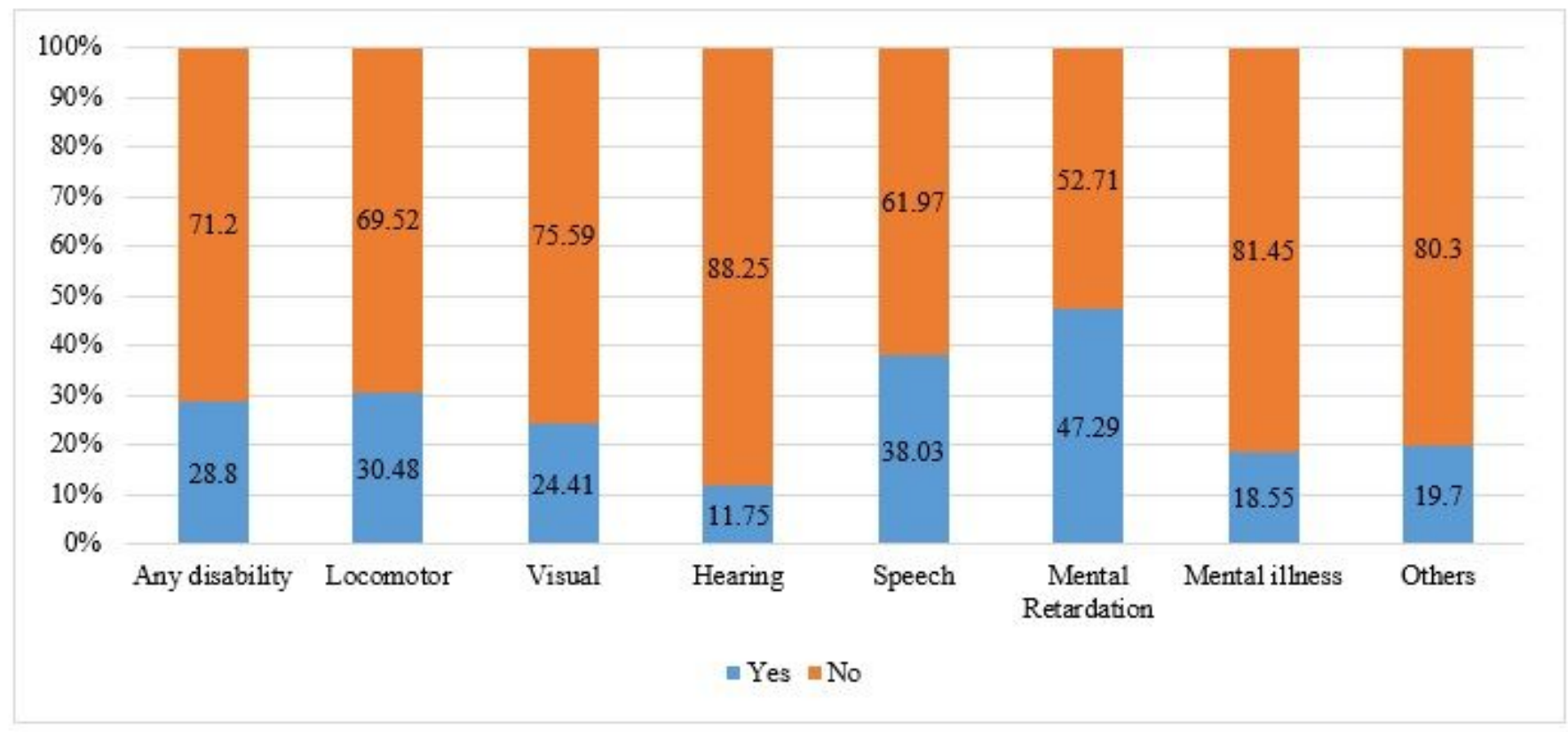

Figure 1

Percentage of disability certificate among type of disabled in India, 2018 


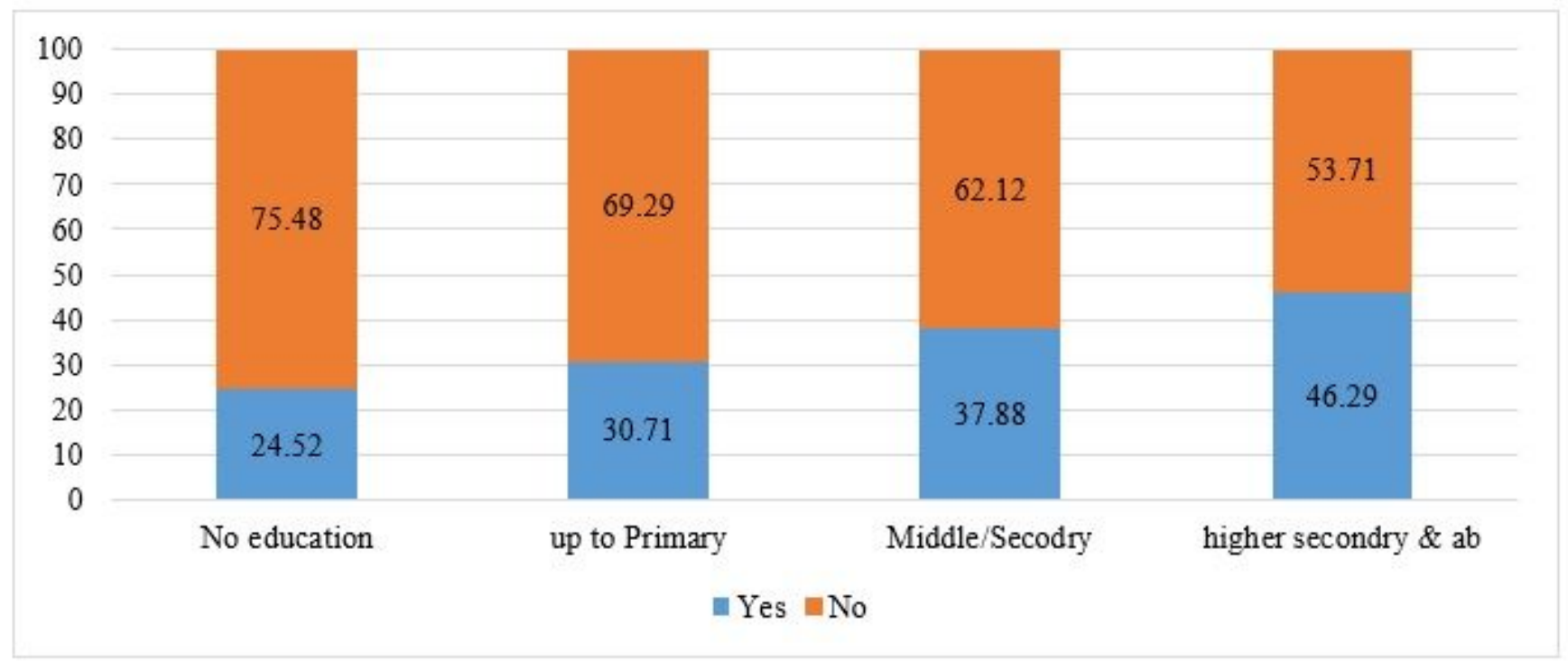

\section{Figure 2}

Percentage of disability certificate among disabled by educational level in India, 2018 